\title{
Krzysztof Tarkowski
}

Uniwersytet Mikołaja Kopernika w Toruniu

\author{
Ewa Bińczyk, Aleksandra Derra, Janusz Grygieńć, Horyzont \\ Konstruktywizmu. Inspiracje, perspektywy, przysztość, \\ Wydawnictwo Naukowe UMK, Toruń 2015, ss. 552.
}

$20 / 2016$

Political Dialogues

DOI: http://dx.doi.org/10.12775/DP.2016.030

\section{Przeciw nieporozumieniom konstruktywizm i jego wcielenia}

W 2015 roku nakładem Wydawnictwa Naukowego UMK ukazała się książka Horyzonty konstruktywizmu. Inspiracje, perspektywy, przyszłość. Składa się ona $z$ trzech części. W pierwszej nazwanej "Tradycje” znajduja się przekłady czterech tekstów znaczących współczesnych myślicieli: Iana Hackinga, Richarda Rorty'ego, Josefa Mitterera oraz Petera Wehlinga. Druga część rozpoczyna się Manifestem toruńskiej szkoły konstruktywistycznej ${ }^{1}$ składajacym się $z$ ośmiu postulatów, które stanowią ramę programowa dla tradycji i kierunków propagowanych oraz rozwijanych przez nieformalna grupę badaczy $z$ Uniwersytetu Mikołaja Kopernika. Omawiana część zawiera przedruki fragmentów książek oraz artykułów badaczy i badaczek z UMK (filozofów i socjologów), w których podejmuja oni zarówno klasyczne tematy konstruktywistyczne, jak i dyskutuja najnowsze tendencje występujace w ramach konstruktywizmu. Znalazły się tu

1 Pierwotnie manifest ukazał się w Przegladzie Kulturoznawczym, 2013, nr 1 (15). Numer tego czasopisma w całości został poświęcony toruńskiej szkole konstruktywistycznej. Znajdzie tam czytelnik więcej informacji o charakterze i genezie grupy. zarówno tekst Andrzeja Zybertowicza Konstruktywistyczny model poznania, jak i artykuł Andrzeja Szahaja O tak zwanym mocnym programie socjologii wiedzy szkoły edynburskiej. Ostatnia część zatytułowana „Komentarze i zastosowania" składa się $z$ dziesięciu tekstów osób luźniej związanych z toruńska szkoła, w których podjęte zostaja rozmaite zagadnienia w dość swobodny sposób nawiązujące do postulatów manifestu. Znajdujemy tam teksty komentujace $\mathrm{m}$. in. nie-dualizujacy sposób mówienia Mitterera, założenia poznawcze ekonomii czy zagadnienie reprezentacji w filozofii Roberta Brandoma.

Biorac pod uwage ilość artykułów oraz różnorodność podejmowanych przez nie tematów, począwszy od feministycznej krytyki filozofii nauki, przez społeczno-kulturowe uwarunkowania matematyki, na technologiach udoskonalania człowieka kończac, nie sposób w tak krótkiej formie, jaka jest recenzja, odnieść się do nich wszystkich. Ze względu na szeroko rozumiany tytułowy konstruktywizm problemem jest również doprecyzowanie wspólnego mianownika dla wszystkich rozważań obecnych w ksiażce. Dlatego skupię uwage na kilku wybranych tekstach, zagadnieniach i aspektach. 


\section{Konstruktywizm i nauka}

Konstruktywizm jest pojęciem, które można rozumieć bardzo szeroko. Jego sednem jest twierdzenie o aktywnej roli podmiotu w poznaniu czy wytwarzaniu wiedzy, które można wywodzić $z$ filozofii Kanta. Takie ogólne ujęcie konstruktywizmu, w duchu neopragmatyzmu, stanowi raczej podstawę rozważań zawartych w książce, niż jej główny przedmiot. Nie oznacza to jednak, że wątków ogólnofilozoficznych w ogóle w niej nie ma, czego wyrazem jest choćby tekst Richarda Rorty'ego. Autor podejmuje w nim rozważania metafilozoficzne wyróżniając trzy stanowiska i ich przedstawicieli: Husserla traktujaccego filozofię jako swoiście rozumiana naukę, której zadaniem jest docieranie do istot rzeczy, Heideggera rozpoznającego w niej rodzaj sztuki oraz Deweya, który dopatruje się w niej głównie narzędzia politycznego pozwalającego na ucisk bądź emancypację. Największa różnica jest między stanowiskiem pierwszym a drugim i trzecim. Jak widać samo odrzucenie esencjalizmu nie przesadza o kształcie filozofii i jej roli w społeczeństwie.

Powiedzenie, że konstruktywizm jest konkretnym, dookreślonym stanowiskiem (epistemologicznym? metodologicznym? retorycznym?) byłoby tylko słownym a zatem pozornym uproszczeniem. Aby uniknąć nieporozumień wynikających $z$ wieloznaczności należy podkreślić, że konstruktywizmów jest wiele. Różnią się zarówno radykalnością stawianych twierdzeń, jak i stosowanymi narzędziami ich uskuteczniania. Czasami mamy też do czynienia $z$ dość swobodnym posługiwaniem się pojęciem konstruktywizmu społecznego. Odgrywa on wówczas rolę użytecznej metafory w przeróżnych obszarach dociekań.

Dla lepszego zrozumienia tytułowego konstruktywizm możemy siegnać do postulatów zawartych w manifeście. Znajdziemy tam ogólne sformułowanie: „przyjmujemy antyesencjalizm (przede wszystkim w rozumieniu faktów naukowych i podmiotu), historyzm, relacjonizm oraz antydualizm" (pkt 5). W tej szerokiej ramie możemy wyróżnić, za Ewą Bińczyk, cztery podstawowe tradycje konstruktywizmu. Oprócz teorii inspirowanych socjologia wiedzy, wyróżnia ona pokantowskie teorie poznania, konstruktywizm w badaniach literackich oraz najbardziej reprezentatywna dla toruńskiej szkoły tradycje konstruktywizmu w badaniach nad nauką2 (s. 209-212).

$\mathrm{Na}$ pierwszy plan zainteresowań toruńskiej szkoły wysuwa się nauka. $\mathrm{Na}$ ukę w filozofii traktowano przeważnie przez pryzmat jej treści, była ona więc przede wszystkim systemem „prawdziwych zdań empirycznych"3. Oczywiście zdawano sobie sprawę, że tworza ja ludzie zakorzenieni w kontekście społecznym i kulturowym, był on jednak traktowany jako nieistotny. Wynikało to z pewnych metazałożeń towarzyszących refleksji nad nauka, wśród nich możemy wymienić teoriocentryzm, przekonanie o uniwersalności twierdzeń naukowych, neutralności normatywnej stosowanych przez naukę pojęć, a także ścisła, nomologiczna przewidywalność stanowiąca cel

2 Warto wspomnieć o książkach $z$ obszaru badań nad nauką, które ukazały się dzięki wysiłkom torunskkich badaczy: Bruno Latour, Splatajac na nowo to, co społeczne. Wprowadzenie do teorii aktora-sieci, tłum. Aleksandra Derra, Krzysztof Abriszewski, Wydawnictwo Universitas, Wrocław 2010; Bruno Latour, Nadzieja Pandory. Eseje o rzeczywistości $w$ studiach nad nauka $i$ technologia, (red.) Krzysztof Abriszewski, thum. zbiorowe, Wydawnictwo Naukowe UMK, Toruń 2013; Binczyk Ewa, Derra Aleksandra (red.), Studia nad nauka i technologia. Wybór tekstów, Wydawnictwo Naukowe UMK, Torun 2014.

3 Moritz Schlick, Przewrót $w$ filozofii [w:] (red.) Bronisław Baczko, Socjologia i filozofia w XX wieku, t. 2, Wiedza Powszechna, Warszawa 1965, s. 389. 
nauki. Takie spojrzenie na naukę wynikało również, a może przede wszystkim, $z$ pewnych założeń dotyczących roli języka, który traktowany był jako neutralne medium odwzorowywania świata.

Wszystkie te założenia zostały w XX wieku podważone, co umożliwiło odmienne spojrzenie na naukę i jej rolę pełniona $\mathrm{w}$ społeczeństwie. $\mathrm{W}$ manifeście odnajdziemy postulaty dotyczace odejścia od teoriocentryzmu, skupienia uwagi na wytwarzaniu faktów i czynnikach, które na ten proces wpływaja, ze szczególnym uwzględnieniem uwikłania kulturowego. Nauka w takiej perspektywie nie jest już systemem twierdzeń, ale pewna praktyka społeczną. Ujmowanie treści nauki w oderwaniu od usytuowanej działalności jest zdaniem członków toruńskiej szkoły nie tylko sztuczne, ale również niemożliwe do pełnego przeprowadzenia (s. 105). Nauka, traktowana jako przedsięwzięcie zbiorowe nie jest już bezproblemowym dochodzeniem do prawdy, ale stanowi zaangażowane etycznie i politycznie przedsięwzięcie społeczne.

Jak podkreśla recenzowane opracowanie, wraz ze zwrotem postkonstruktywistycznym, który należy rozumieć raczej jako etap ewolucji samego konstruktywizmu, niż odwrót do niego (s. 209), dokonało się jeszcze radykalniejsze odejście od teoriocentryzmu. Przestano skupiać się na społecznym wytwarzaniu treści nauki. Ciężar rozważań spoczą na szeroko pojętej praktyce, której postać wyznaczają wszak także założenia o charakterze dyskursywnym. W zwią$\mathrm{ku} \mathrm{z}$ tym $\mathrm{w}$ omawianym ujęciu wiedza nie jest już czymś, co można posiadać czy przekazać, lecz staje się nieodłącznie spleciona $z$ pewna praktyką czy sytuacja, w której badacz uczestniczy. Uwypuklono rolę czynników pozaludzkich, wskazując na ich swoistą sprawczość (s. 216). Paradygmatycznym miejscem, w którym odbywa się nauka jest w optyce postkonstruktywistycznej laboratorium, lecz nie jako konkretne pomieszczenie, ale szeroko pojęte miejsce manipulacji (s. 367).

Szereg tekstów zawartych w recenzowanym tomie ukazuje rodzaje konstruktywizmów oraz ich założenia. Szczególne miejsce zajmuje konstruktywizm w nauce, zaprezentowany najpełniej.

\section{Feminizmy i nauka}

W czwartym postulacie manifestu torunskiej szkoły konstruktywistycznej znajdziemy stwierdzenie o inspirującym charakterze „(post) feministycznych badań nad nauka". W recenzowanym tomie wyrazem tego podejścia jest tekst Aleksandry Derry $^{4}$, w którym prezentuje ona istotny wkład feminizmu do refleksji nad nauka oraz przeprowadza autorski podział nurtów feministycznej filozofii nauki.

Autorka zauważa, że niektórym myślicielom zwiazek nauki $z$ feminizmem może wydawać się paradoksalny (s. 236). Po części wynika to $z$ tego, że nauka była postrzegana jako czysto racjonalne i empiryczne przedsięwzięcie służące poznawaniu świata, natomiast feminizm traktowany był jako stanowisko społeczno-polityczne, które dąży do realizowania konkretnych celów. Zmiana podejścia $\mathrm{w}$ refleksji nad nauką, która dokonała się w latach siedemdziesiątych $\mathrm{XX}$ wieku, pozwoliła ukazać wiele ukrytych założeń, na których wspierała się działalność poznawcza. Feminizm w sposób naturalny zaczął skupiać swoją uwagę na płciowym uwikłaniu pozornie neutralnej nauki.

4 Warto wspomnieć, że autorka jest dobrze zaznajomiona $z$ poruszana tu tematyka, podstawa artykułu jest rozdział z książki: A. Derra, Kobiety (w) nauce. Problem płci we współczesnej filozofii nauki i $w$ praktyce badawczej, Wydawnictwo Naukowe Scholar, Warszawa 2013. 
Feministyczna krytyka nauki ma janusowe oblicze. $Z$ jednej strony, jest ona szeroko zakrojona, dokonuje się na wielu poziomach, $z$ różnych perspektyw o odmiennych stopniach zaangażowania. Z drugiej strony, rozmaitość postulatów, celów i metod badań feministycznych, nie pozwala na stworzenie zgodnego projektu, który miałby szerokie poparcie, a przez to byłby efektywniejszy we wprowadzaniu zmian. Nadmienić trzeba, że zdaniem autorki wszystkie opisywane przez nia nurty działaja na rzecz ulepszenia nauki, zgodnie $z$ zachodnimi ideałami oświeceniowymi traktującymi ja pozytywnie (s. 239).

Pierwszy $z$ wyróżnionych przez autorkę nurtów traktuje naukę jako miejsce możliwie bezstronnych praktyk i dyskursów. Dotychczas nauka była domeną mężczyzn, skutkiem czego było jej stronnicze zniekształcenie. Feminizm powinien zatem dążyć do przywrócenia równowagi poprzez korygowanie patriarchalnych naleciałości. Jest to stanowisko wyraźnie inspirowane klasycznym empiryzmem, lecz uwzględniajace krytykę pozytywistycznego spojrzenia na naukę.

Drugie stanowisko podważa ideę obiektywności nazywając ją naiwną. Feministki $z$ tego nurtu wskazuja na usytuowanie osób zajmujących się nauka oraz na nierówność społeczną w dostępie do jej uprawiania. Nauka zawsze legitymizuje światopogląd osób w lepszej sytuacji, dlatego powinno się uprzywilejować epistemologicznie grupę, która jest zmarginalizowana. Mamy tu do czynienia $z$ nieprzezwyciężalna asymetria, która wyklucza wspólna wszystkim obiektywność. Głównym celem powinno być eksponowanie opresjonowanych punktów widzenia. Warto zauważyć, że w tej perspektywie działalność poznawcza nauki schodzi na dalszy plan, a na czoło wysuwa się jej rola społeczna.
Ostatnie stanowisko post-feministyczne wiąże się $z$ filozofią postmodernistyczna, która w uproszczeniu charakteryzuje „antyesencjalizm, antyfundamentalizm, poszukiwanie zróżnicowania, nieciagłości, zmian, raczej mnożenie czynników, a nie ich redukowanie" (s. 252). Autorka trafnie zauważa, że takie podejście ma watpliwy potencjał społeczno-polityczny. Wyraźnie też zostaje osłabiona kategorii płci, $z$ powodu niepowodzenia XX-wiecznych prób ich definitywnego ustalenia. Płeć zostaje każdorazowo definiowana na nowo, w zależności od doraźnego kontekstu i zawsze w uwikłaniu w inne zmienne. Zdaniem autorki uwzględnianie płci w bieżacych dyskursach jest już rzeczą oczywistą.

We współczesnym, rozparcelowanym świecie anachronizmem jest mówienie o jednej nauce i jej metodzie. Użyteczniej jest mówić o konkretnych praktykach czy teoriach, które możemy analizować i krytykować. Tak jak nie ma jednej nauki, tak samo nie ma jednego rozumienia płci, kobiecości będą się różnić w zależności od kontekstu społecznego, kulturowego czy historycznego. Mimo tych niewspółmierności powinniśmy badać relacje między płcia a nauka w celu tworzenia lepszej nauki. Można by zapytać lepszej dla kogo? Dla wszystkich ludzi - odpowiada autorka, co jest stwierdzeniem tyle optymistycznym, co problematycznym.

\section{Nieporozumienia}

Moją uwage przykuło zagadnienie, które charakteryzuje dużą część tekstów, a tym samym cechuje cała książę. Mam na myśli kwestię nieporozumień. Dotyczą one zarówno samego stanowiska konstruktywistycznego, jak i wewnętrznych sporów w jego ramach. Zastanawiajace jest, że mimo dużej świadomości problemów 
terminologicznych, argumentacyjnych i świadomości trudności wynikajacych z niefrasobliwości w używaniu pojęć, do nieporozumień wciąż dochodzi, stają się przedmiotem artykułów i polemik. $Z$ góry uprzedzam, że nie chodzi mi o fundamentalne podziały filozoficzne i oto czy sa one eliminowalne. Chodzi mi o kwestię dużo mniejszego kalibru, o wskazywanie nieścisłości, niedoczytań i nieżyczliwych interpretacji, co do których nie ma wątpliwości, że takie właśnie są. Wybrałem kilka tekstów, w których temat nieporozumień został podjęty w sposób najbardziej interesujący i obszerny.

Pierwszym myślicielem, który podnosi kwestię nieporozumień w sposób bezpośredni jest Ian Hacking. Prezentuje on przykłady kilkudziesięciu książek zawierajacych w swych pojęcie konstruowania społecznego. Dokonuje on analizy znaczeń, w jakich pojęcie to występuje. Czym innym jest konstruowanie społeczne pojęć czy konotacji, a czym innym szeroko rozumianych przedmiotów. Co innego mamy na myśli mówiąc o konstruowaniu na gruncie nauk społecznych, a co innego w naukach przyrodniczych. Uświadomienie sobie uchodźczyniom, że są uchodźczyniami wpływa w konkretny sposób na ich zachowanie i sposób myślenia o sobie (s. 25). W fizyce o takiej samozwrotności nie ma mowy. Jak wskazuje Hacking, znana książka Petera Bergera i Thomasa Luckmanna Społeczne tworzenie rzeczywistości (1983), mimo sugestywnego tytułu, nie zawiera konstruktywizmu totalnego głoszącego, że nie tylko nasze sposoby myślenia o przedmiotach sa konstruktami, ale same te przedmioty. Hacking jest bardzo sceptycznie nastawiony do tak radykalnego twierdzenia. Niefrasobliwe używanie pojęcia konstruowania społecznego przyczynia się do wielu niepotrzebnych i często zaciętych dyskusji.
Warto nadmienić, że autor sam przyznaje się do nieprecyzyjnego posługiwania się tym pojęciem w przeszłości i uznaje to za swój grzech (s. 48-49).

O trudnościach i rozbieżnościach w ramach konstruktywizmu pisze też w swoim tekście Andrzej Zybertowicz. Wskazuje na pięć głównych zarzutów wobec konstruktywistycznego modelu poznania, dodajac, że „Szereg $z$ nich opiera się na nieporozumieniach" (s. 140). Przykładem moga być liczne dyskusje dotyczace przyczyn praktycznego sukcesu nauki. Sukces ten jedni interpretuja jako świadectwo metafizycznej adekwatności pomiędzy naszymi teoriami a rzeczywistościa, drudzy jako wynik coraz lepszej przewidywalności przyszłych zdarzeń. Autor wyróżnia również cztery rodzaje poznania występujące w obrębie konstruktywizmu, z nadzieją, że „winno to pomóc w uporaniu się $z$ częścia nieporozumień, w jakie wikłaja się badania nad poznaniem" (s. 145). Sa to kolejno: 1) odtwarzanie treści doświadczenia społecznego; 2) odkrywanie zawartości istniejacych gier kulturowych; 3) redefiniowanie istniejacych gier w następstwie kontaktów $z$ innymi grami kulturowymi; 4) projektowanie nowych obszarów doświadczenia kulturowego.

Kolejnym tekstem ukazującym cały szereg nieporozumień i niedoczytań jest polemika Tomasza Markiewki z Hanna Buczyńską-Garewicz, dotycząca stanowiska Richarda Rorty'ego. Spór ogniskuje się wokół pięciu wniosków, do jakich może dojść czytelnik po lekturze książki Buczyńskiej-Garewicz Prawda i złudzenia (2008). Obraz autora Filozofii a zwierciadła natury, jaki się wyłania $z$ tego opracowania „zawiera uproszczenia i nieporozumienia" (s. 191). Autorka interpretuje myśl amerykańskiego filozofia w sposób radykalny, niesłusznie przypisujac mu absurdalne twierdzenia, 
że świat nie istnieje a prawda jest pojęciem, którego powinniśmy się pozbyć.

Autorka Prawdy i złudzeń dokonuje streszczenia poglądów Rorty'ego, lecz jak wykazuje Markiewka, robi to ona w sposób, który prowadzi do absurdalnych wniosków (s. 194). Podaje on szereg kontrprzykładów na potwierdzenie tez przeciwnych. Wskazuje na dookreślenia, którymi Rorty opatruje swoje twierdzenia oraz zauważa nieuzasadnione generalizacje autorki. Markiewka zwraca również autorce Prawdy i złudzeń uwagę na dokonywanie dosyć swobodnych przeskoków między potocznym rozumieniem pojęcia prawdy a metafizycznym (s. 199). Krytyka jest o tyle ważna, że wnioski do jakich dochodzi Buczyńska-Garewicz sa obce filozofii Rorty'ego. Jak się wydaje, Markiewka dokonuje swojej krytyki w sposób rzetelny, przywołując na potwierdzenie swoich zarzutów szereg oryginalnych stwierdzeń amerykańskiego autora.

Ciężko oprzeć się stwierdzeniu, że niektóre interpretacje stanowisk na pozór kontrowersyjnych są często wynikiem znacznej dozy nieżyczliwości danego komentatora czy komentatorki ${ }^{5}$. Nie będę w tym miejscu dociekał, czym takie nastawienie może być powodowane. W każdym razie wydaje mi się ono równie szkodliwe dla praktyki akademickiej, co naukowa nierzetelność.

Odnoszę wrażenie, że szeroko pojęte stanowiska konstruktywistyczne sa szczególnie podatne na błędne odczytania, a tym samym na nietrafna krytykę. Nie wynika $z$ tego, że nie istnieje uzasad-

5 Dosadnym przykładem takiego podejścia jest uwaga Agnieszki Kołakowskiej pod adresem Bruno Latoura i jego słów, że fizyka to jedynie język. Autorka stwierdza, że gdyby francuski filozof miał rację, to nie istniałyby samoloty, zob. Wojny kultur i inne wojny, Wydawnictwo Teologia Polityczna, Warszawa 2010, s. 223. niona krytyka, czego najdoskonalszym przykładem może być odchodzenie badaczy od społecznego konstruktywizmu i sprzyjanie postkonstruktywizmowi, co nastapiło w odpowiedzi na konkretne zarzuty (s. 100-101; 216-222). Ze względu na owa podatność ważnym aspektem recenzowanej ksiażki jest uprzedzanie ewentualnych nieporozumień oraz konfrontowanie się $z$ nimi. Mam nadzieję, że przyczyni się to w dużym stopniu do podniesienia jakości dyskusji, polemik i konstruktywnej krytyki wobec konstruktywizmu.

$$
* * *
$$

Uważam, że ksiażka jest godna polecenia, natomiast problemem jest pytanie do kogo dokładnie jest ona adresowana? Zawiera ona komentarze do szeroko rozumianego konstruktywizmu rozwijanego przez toruńska szkołę. Wątpliwości może budzić jednak sam pomysł na taki kształt książki, który ma odzwierciedlać bogactwo tematyki konstruktywistycznej, a także być źródłem wielorakich inspiracji. Wielość tematów i perspektyw zmusza do postawienia pytania o ich wspólny mianownik. Odwołując się do przywołanego już piątego postulatu manifestu, który mówi o antyesencjalizmie, można wskazać dość ogólną wspólną perspektywę, w której sytuuja się wszystkie teksty. Jak już wspomniałem, dotyczy ona konstruktywizmu związanego $z$ nauka.

Horyzonty konstruktywizmu to bardzo dobre wprowadzenie we współczesna tematykę konstruktywistyczną i postkonstruktywistyczna. Zawiera ona klasyczne teksty zarówno zagranicznych, jak i polskich badaczy. Podjęte w nich tematy sa ukazane przejrzyście i spójnie. Autorzy dokonują szeregu rozróżnień i konfrontuja się z zarzutami. Wszystko to pozwala żywić nadzieję, że recen- 
zowana książka nie tylko przyczyni się do upowszechnienia perspektywy konstruktywistycznej ale przede wszystkim, że dokona tego w sposób, który pozwoli uniknąc dalszych nieporozumien. Zamiast na nietrafne zarzuty wysiłki polskich badaczy zostaną spożytkowane na konstruktywna krytykę i wykorzystanie narzędzi oferowanych przez (post)konstruktywizm w praktyce. 